УДК 821.І6І.І.о

ББК $83.3(2 \mathrm{Poc}=\mathrm{Pyc}) 52$
О ПРАГМАТИКЕ ЖАНРА $И$

ИСТОЧНИКОВЕДЧЕСКОМ РЕСУРСЕ «ЛИТЕРАТУРНЫХ» ВОСПОМИНАНИЙ О ПОЗДНЕМ ГОГОЛЕ

\author{
(C) 2020 г. Е.Г. Падерина \\ Институт мировой литературы \\ им. А.М. Горького Российской академии наук, \\ Москва, Россия \\ Дата поступления статьи: г7 декабря 20192. \\ Дата публикации: 25 декабря 20202.
}

DOI: https://doi.org/IO.22455/2500-4247-2020-5-4-222-245

Работа выполнена при поддержке гранта РФФИ № 20-ог2-оогз9а

Аннотация: В статье рассматривается известный по мемуарам эпизод гоголевской биографии. Он засвидетельствован в четырех мемуарных текстах -

И.И. Панаева, А.Я. Панаевой, П.В. Анненкова и Н.А. Некрасова. Речь идет об одной и той же вроде бы встрече Гоголя с «молодыми литераторами» в конце I840-х гг. в Петербурге. Но событие описано по-разному и во всех случаях с явными ошибками в датах и в других сведениях. Автор статьи подробно рассматривает источниковедческий ресурс конкретного мемуарного эпизода и приходит к следующему выводу: комплекс сведений о гоголевской встрече с «литературной молодежью» конца I840-х гг. многое сообщает о характере восприятия младшими (по возрасту и одаренности) современниками личности Гоголя, а также о типологии и эволюции мемуарных жанров второй половины XIX в. Но надежность биографических данных о Гоголе слишком мала. Совокупный объем сведений указывает на вероятность самой встречи, но ставит под сомнение практически все подробности этого события. Названные мемуаристами участники (Гончаров, Григорович, Дружинин и др.) об этой важной встрече промолчали, и доступные современному гоголеведению данные не позволяют что-либо подтвердить и извлечь для научной биографии Гоголя без оговорок о гипотетичности.

Ключевые слова: поздний Гоголь, биография, мемуары, И.И. Панаев, А.Я. Панаева, Н.А. Некрасов.

Информация об авторе: Екатерина Геннадьевна Падерина - доктор филологических наук, ведущий научный сотрудник, Институт мировой литературы им. А.М. Горького Российской академии наук, ул. Поварская, д. 25 а, І2Іо69 г. Москва, Россия. ORCID ID: https://orcid.org/oooo-0002-8970-7269

E-mail: kbogan@yandex.ru

Для цитирования: Падерина Е.Г. О прагматике жанра и источниковедческом ресурсе «литературных» воспоминаний о позднем Гоголе // Studia Litterarum. 2020. T. 5, № 4. C. 222-245. https://doi.org/I0.22455/2500-4247-2020-5-4-222-245 




This is an open access article distributed under the Creative Commons Attribution 4.0 International (CC BY 4.0)

\section{ON THE PRAGMATICS OF THE GENRE AND THE SOURCE OF THE "LITERARY" MEMORIES ABOUT LATE GOGOL}

\author{
(C) 2020. E.G. Paderina \\ A.M. Gorky Institute of World Literature \\ of the Russian Academy of Sciences, Moscow, Russia \\ Received: December I7, 2019 \\ Date of publication: December 25, 2020
}

Acknowledgements: This work was supported by the Russian Foundation for Basic Research (RFBR) grant No. 20-OI2-OOI39a.

Abstract: This essay examines an episode of Nikolay Gogol's biography described in four memoir texts - by I.I. Panayev, A.YA. Panaeva, P.V. Annenkov, and N.A. Nekrasov. All the four texts tell the story of Gogol meeting "young writers" in St. Petersburg in the late I840s. As it often happens in memoirs, the authors describe the same event differently. The author of this article thoroughly examines the sources of this particular episode and comes to the following conclusion. The memoirs of Gogol`s meeting with the "young writers" in the late I840s tells us a lot about how Gogol's personality was perceived by his younger and less famous contemporaries. It also sheds light on the typology and evolution of memoir genres in the second half of the $19^{\text {th }}$ century. Yet the reliability of biographical data about Gogol is insufficient. The total amount of information indicates the probability that the meeting took place but gives a reason to doubt almost all the details of this event. The participants named by the authors of the memoirs (Goncharov, Grigorovich, Druzhinin, etc.) kept silent about this important meeting while the data available to modern Gogol scholars points at the hypothetical character of the mentioned episode.

Keywords: late Gogol, biography, memoirs, I. Panaev, A. Panaeva, N. Nekrasov

Information about the author: Ekaterina G. Paderina, DSc in Philology, Leading Research Fellow, A.M. Gorky Institute of World Literature of the Russian Academy of Sciences, Povarskaya 25 a, I21069 Moscow, Russia.

ORCID ID: https://orcid.org/oooo-0002-8970-7269

E-mail: kbogan@yandex.ru

For citation: Paderina E.G. On the Pragmatics of the Genre and the Source of the "Literary" Memories about Late Gogol. Studia Litterarum, 2020, vol. 5, no 4, pp. 222-245. (In Russ.) https://doi.org/IO.22455/2500-4247-2020-5-4-222-245 
Мемуары - важный для писательской биографии вид источников, но, как известно, - с условной фактической надежностью. А это остается основным критерием оценки источниковедческого ресурса, хотя достоверность как качество сообщенного может относиться к разным уровням, компонентам и сегментам воспоминания - в зависимости от исследовательских задач и мемуарного жанра. Понятно, что извлечение из мемуарного моря всего, что относится к одному писателю, расширяет возможности: в комплексе учитываемых факторов в таком случае увеличивается роль жанровой специфики и эволюции, мифопорождающих тенденций исторического периода, прагматических аспектов извлечения из памяти подробностей о прошлом и адресации результатов, фактора редактирования (автором, наследником-публикатором, потомком-текстологом и т. п.), а также влияния опубликованного писательского наследия и мемуарного корпуса на работу со своей памятью следующих вспоминателей․ При этом многое зависит от времени и личности писателя, чья биография составляет фокус взаимодействия мемуарного поля с исследовательским.

Гоголь в мемуаристике - лицо во многих отношениях особое. Первым из наших классиков он был при жизни и признан гением, и с этого пьедестала низведен, первым разомкнул свою писательскую биографию для широкого читателя и допустил в свою внутреннюю жизнь всех и вся, но - только за пределами живого общения, где не всегда был открыт и для друзей ${ }^{2}$, а для сторонних - совершенно замкнут. В итоге все те, кто был с

I См. обзор проблематики: [12, с. 8-27].

2 Ср.: «Даже с друзьями своими он не был вполне или, лучше сказать, всегда откровенен. Он не любил говорить ни о своем нравственном настроении, ни о своих житейских обсто- 
ним знаком, по его смерти оказались, надо сказать, в очень непростом положении. Друзья ощущали особую ответственность и перед современниками, жаждущими всякого сообщения об ушедшем гении, чья смерть осиротила отечественную литературу, и перед потомками, которым предстояло разобраться в сложных и запутанных хитросплетениях гоголевского характера и его судьбы, и перед самим Гоголем, разумеется, - перед памятью о друге (и, например, С.Т. Аксаков и А.О. Смирнова не торопились обнародовать свои мемуары о Гоголез, хотя сбережением всего памятного занялись сразу). Знакомые же, приятели и однократно встретившие его в жизни люди испытывали естественную потребность засвидетельствовать свою причастность к биографии великого человека, что приводит, как писал Ю.М. Лотман, «к рождению в ряде случаев мифологических, анекдотических и пр. псевдобиографий <...>, рождает сплетни и спрос на мемуарную литературу» [г3, с. го9]. Так оценивали ситуацию и гоголевские современники: «Еще ни один русский писатель <...> никогда не возбуждал о себе столько противоречащих суждений и толков при жизни и после смерти; еще никогда ни об одном русском писателе не собирали с таким усердием самых мелочных, микроскопических фактов; еще никогда ни один из русских писателей не возбуждал такого жаркого энтузиазма; еще ни одним литературным именем не спекулировали так, как именем Гоголя» ${ }^{4}$

Разумеется, отбор мемуарных, эпистолярных и дневниковых (в разном сочетании) сообщений и суждений о Гоголе - человеке и писателе - отсеивал сомнительные данные, не подтвержденные сегменты отбрасывались или особо оговаривалась степень уверенности в них, и в большинстве своем соответствующие издания очищены в этом плане. Последний «систематический свод», составленный И.А. Виноградовым (20II-20I3), содержит все что ни есть, как кажется, сообщения о Гоголе, упоминания и суждения о нем. И это позволяет ожидать в перспективе системно-аналитического ис-

ятельствах, ни о том, что он пишет, ни о своих делах семейных». См.: <Аксаков С.T.> С.А. Письмо к друзьям Гоголя // Московские Ведомости. I852. № 32. І3 марта. С. 328.

3 С.Т. Аксаков писал через год после смерти Гоголя, что его биографию нельзя «скоро напечатать по свежести отношений покойного к живым людям, но даже и нельзя беспристрастно написать», что она «заключает в себе особенную, исключительную трудность, может быть единственную в своем роде». См.: <Аксаков С.Т.> С.А-в. Несколько слов о биографии Гоголя // Московские Ведомости. І853. № 35. 21 марта. С. 360.

$4<$ Панаев И.И.> Заметки и размышления Нового поэта по поводу русской журналистики // Современник. І855. № 6. Отд. «Смесь». С. 254. 
следования всех мемуаров о Гоголе, выявления разных тенденций (от исторических до конкретно-субъективных), установления типологических, а то и генетических связей, описания проблем изучения этого типа источников гоголеведением и т. п. 5

Но пока, в отсутствии системного исследования такого рода, обойтись без изучения прагматического аспекта каждого мемуарного источника мы не можем.

Заинтересовавшие нас сообщения о встрече Гоголя с «молодыми литераторами» в конце І840-х гг. в Петербурге относятся к сомнительным, однако используемым и потому требующим разбирательства источникам. Событие засвидетельствовано в четырех мемуарных текстах: три записаны авторами - И.И. Панаевым, А.Я. Головачевой-Панаевой и П.В. Анненковым, а один, Н.А. Некрасова, известен в изложении А.А. Суворина. Речь идет об одной и той же вроде бы встрече, но, как это часто бывает в мемуаристике, описана она по-разному и приурочена к разным годам, и не просто к разным, а к тем, когда Гоголь вовсе не мог в ней участвовать. У Панаевой это г847 г. ${ }^{6}$, у Анненкова - І849 г.7, у Панаева - г849 или г850 г. («года два или три после смерти Белинского» ${ }^{8}$ ), а Гоголь был в Петербурге только осенью I848 г. Эти «ошибки памяти» давно исправлены комментаторами, но датами не исчерпываются неувязки своеобразного крыловского «квартета», одна из партий которого - И.И. Панаева - известна в разных печатных редакциях.

Некрасов и Головачева-Панаева, например, запомнили, что на встрече был и Белинский, хотя он умер за несколько месяцев до приезда Гоголя в Петербург. Естественно, исправлена и эта аберрация памяти, но у Панаевой, в частности, есть и другие, да и в целом то, что ей «вспомнилось» о встрече, вообще не могло произойти. Гоголь «всплыл» в ее памяти посреди описания впечатлений от встреч с Белинским, поэтому и событие она приурочила к I847 г., когда критик был жив, и даже описала, как и из чего «на другой день»

5 Ср. плодотворный опыт в пушкинистике: [І2].

6 Воспоминания А.Я. Головачевой (Панаевой). Гл. VIII // Исторический вестник. I889. T. 36. № 4. С. 54 .

7 Последняя встреча с Гоголем (Из воспоминаний П.В. Анненкова о Москве осенью І85г года) // П.В. Анненков и его друзья: Литературные воспоминания и переписка І835-г885 годов. СПб.: Изд-е А.С. Суворина, І892. С. 5 І5.

8 Панаев И.И. Воспоминание о Белинском // Современник. І86о. Т. 79. № г. С. 365. 
после встречи в петербургском доме Панаева родилось знаменитое письмо Белинского к Гоголю9, прочитанное как будто бы сначала хозяину дома, а после переданное Гоголю «частным образом» ${ }^{\text {г }}$. Такую степень «забывчивости» в датах и фактах, тут же замеченную и опровергнутую в печати В.И. Шенроком $^{\mathrm{II}}$, не может объяснить и большая временная дистанция (мемуары написаны в конце г880-х гг.). Сплетнический характер ее воспоминаний известен ${ }^{\mathrm{I2}}$, К.И. Чуковский считал, что «вульгаризация» в стиле и тоне не отменяет верного отражения эпохи, но и он назвал «ошибкой чудовищной» ${ }^{\text {13 } э п и з о д, ~ в ~ к о-~}$ тором мемуаристка заставила встретиться в петербургском доме Панаева в I847 г. - Гоголя, бывшего тогда в паломнической поездке на Святую Землю, и Белинского, лечившегося в Саксонии. Если бы она заботилась о достоверности, то с легкостью могла бы скорректировать свою «память» о встрече, заглянув в биографию того или другого, но задачи она решала другие ${ }^{\mathrm{I}}$, и мемуарный жанр был для нее востребованной читателем литературной формой.

К чему мы, однако, подробно о Панаевой-мемуаристке? Зачем, кажется, ломать давно сломанные стулья? Ясно, что этот источник не имеет отношения к позднему Гоголю (и даже более того - к восприятию его в той литературной среде, с которой беллетристка была связана) и не сообщает ничего о вероятной встрече. Далеко не все биографы и комментаторы минувшего времени, надо сказать, посчитали достойным упоминания и саму вероятную встречу, ну и никто по ее поводу не стал всерьез обсуждать мемуарную беллетристику Панаевой ${ }^{15}$. Ю.В. Манн в новейшей биографии

9 Ср. устное «пламенное» высказывание Белинского в качестве прототекста знаменитого «письма»: «Не хотел выслушать правды - убежал!.. еще лучше. Я в письме изложу ему все!.. Нет, с Гоголем что-то творится... И что за тон он принял на себя, точно директор департамента, которому представляют его подчиненных чиновников... Зачем приезжал?». См.: Воспоминания А.Я. Головачевой (Панаевой). Гл. VIII. С. 54.

Iо Воспоминания А.Я. Головачевой (Панаевой). Гл. VIII. С. 55.

II B одном из следующих номеров журнала В.И. Шенрок написал: «Это сообщение решительно противоречит тем несомненным фактам, которые нам известны, по крайней мере, до сих пор», и привел эти факты, опровергающие буквально каждое слово мемуаристки. См.: Шенрок В. К воспоминаниям А.Я. Головачевой // Исторический Вестник. І889. Т. 36. № 5 . Отд. «Заметки и поправки». С. 477, 478.

I2 Чуковский К. Панаева // Чуковский К. Некрасов: Статьи и материалы. Л.: Кубуч, І926. C. IO2.

I3 Там же.

I4 «Зато книга читается, как бульварный роман <...>. Все в ней живописно, драматично, эффектно». См.: Чуковский К. Панаева... С. го2.

I5 О встрече не упомянул В.И. Шенрок в «Материалах к биографии Н.В. Гоголя» (г896), 
Гоголя справедливо называет это сообщение Панаевой о Гоголе и Белинском - «совершенно фантастичным» [I4, c. I5I] и тоже исключает из обсуждаемых версий.

Исключили бы и мы, но другой современный научный источник не позволяет нам обойти ее вниманием. Дело в том, что автор новейшей «Летописи жизни и творчества Н.В. Гоголя» (далее - ЛЖТ), приводит версию Панаевой почти полностью (отрезана только «развязка» новеллы - устная реплика Белинского и сообщение о чтении им своего пламенного письма хозяину дома, т. е. Панаеву [5, с. I73] $\left.{ }^{16}\right)$, приводит - наряду с другими тремя сообщениями о встрече в привязке к точной дате (как и требует этот тип научного издания) - «25 сентября или 2 октября I848 г.» [5, с. I69]. Конечно, исправлена «ошибка» Панаевой в дате, хотя оставлено без комментариев противоречие в месте встречи (дом бывшего мужа), сделавшее ее «свидетельницей». Но хоть бы место действия и было исправлено комментатором, не теряет остроты вопрос: что, собственно, сообщает (или что подтверждает) цитируемый в ЛЖТ фрагмент воспоминаний Панаевой - о «жизни и творчестве» Гоголя и непосредственно о его пребывании в Петербурге в I848 г.? Почему (задаемся мы вторым, тоже риторическим, вопросом) автор-составитель совершенно доверяет знаменитой своей «плохой памятью» мемуаристке и даже включил в описание «факта» жизни Гоголя упомянутых только ею В.П. Боткина и А.И. Кронеберга в число молодых литераторов, «за час до прибытия Гоголя» как будто бы собравшихся в кабинете Панаева [5, с. І69]?

Вернемся, впрочем, от не имеющих ответа вопросов к обсуждению коллективной памяти о встрече Гоголя с литературной молодежью и присмотримся к каждой партии в оставшемся мемуарном «трио». В соответ-

\footnotetext{
А.И. Кирпичников в «Опыте хронологической канвы к биографии Н.В. Гоголя» (1902), С.И. Машинский в издании «Гоголь в воспоминаниях современников» (I952). В.В. Гиппиус привел фрагмент из «Воспоминаний о Белинском» И. Панаева в своде эпистолярных и мемуарных данных о Гоголе (193I), уточнив дату, а сообщение Головачевой-Панаевой назвал «совершенно неправдоподобным» (см.: Н.В. Гоголь в письмах и воспоминаниях / сост. В. Гиппиус. М.: Изд-во «Федерация», г93г. С. 379); так же сделал В. Вересаев (1933) в «систематическом своде подлинных свидетельств».

I6 Но в выборке для «полного систематического свода документальных свидетельств» 0 Гоголе, составленного ранее автором ЛЖТ, фантастическая концовка есть [6, с. 289], и слава Богу, поскольку она точно индексирует ничтожную меру документализма воспоминания беллетристки, затушеванную в ЛЖТ.
} 
ствии с хронологией «свидетельства» располагаются так: Панаев впервые вспомнил об этом в І855 г., потом еще раз - в I860 г., Некрасов - в I875 г. (когда Суворин занес его рассказ в свой дневник [6, с. 643]), наконец, Анненков - не ранее конца I877 г. [9, с. 647-648].

Хронология, как видим, указывает на то, что мемуары И.И. Панаева могут оказаться более надежным источником. А потому начнем с них. Надо сказать, что его описание эпизода воспроизводилось ранее только в редакции I86о г. ${ }^{17}$, т. е. извлекалось из «Воспоминаний о Белинском». Между тем впервые Панаев «вспомнил» об этом не в мемуарах, а в своем журнальном фельетоне «Заметки и размышления Нового поэта по поводу русской журналистики». А это совсем другой жанр, другие авторские установки (включая полемические цели, ироническую модальность и пародийные формы подачи «рассуждений» об актуальном литературном процессе, ну и - речевого посредника в виде устойчивой литературной маски $)^{18}$. Посмотрим, каков буквальный контекст сообщения о Гоголе.

Ближайшие обстоятельства появления фельетона связаны с упомянутым выше мемуарным бумом первых лет по смерти Гоголя. С.Т. Аксаков в марте I853 г., выдержав год, призвал современников не спекулировать на имени писателя и не торопиться с обнародованием не вполне корректных, неточных данных ${ }^{19}$. Но поток не прекратился. И в I855 г. энтузиазм накопления «материалов для биографии Гоголя» стал темой очередного фельетона «Современника». Подчеркнув никчемность большинства мемуарных сообщений о Гоголе, фельетонист описал разнообразие мотивов вспоминателей: «Добродушные люди, которые встретили его один раз в жизни, как-нибудь случайно и даже не поменялись с ним ни одним словом, уже считают долгом писать об нем свои воспоминания; люди расчетливые собирают самые незначущие его записочки и письма к приятелям и более или менее искусно связав их собственными размышлениями, - мечтают о продаже этих записочек и писем в свою пользу и о приобретении себе не-

I7 См. в настоящей статье примеч. № Іо; исключением стал «систематический свод», составленный И.А. Виноградовым, где приведены оба варианта - I855 и І860 гг.

I8 См. о поэтике журнальных фельетонов и прагматике жанра: <Панаев И.И.> Заметки и размышления по поводу русского фельетона // Современник. 1852. Т. 35. № Iо. С. 239-255. См. также: [Iо, с. 8I-IOI; 4, c. IO-II, I8-I9].

I9 <Аксаков С.T.> С. А-в. Несколько слов о биографии Гоголя // Московские Ведомости. 1853. № 35. 21 марта. С. 360. 
большого капитальца на счет имени Гоголя; есть и такие, я думаю, которые не упустят случая прихвастнуть печатно знакомством с покойным и охотно готовы пофантазировать, пожалуй, на его счет... Кто же возьмется уличать таких господ?..»²0. Следом, в пример, пересказана «одна статейка» (не напечатанная, а показанная «знакомым журналистом»), где кроме «стереотипных фраз о значении Гоголя» - лишь разные «незначущие» мелочи (цвет жилета, произнесенное Гоголем междометие с парой слов и т. п.), и подведен итог: «И это называется материалами для биографии!»². Вот к этой критике мемуарной мелочности Панаев и присоединил свое «воспоминание» - в качестве примера того, какие воспоминания о Гоголе могут иметь хотя бы какое-то значение для биографа, согласно самому ироническому комментарию фельетониста. «Если бы я вздумал идти за так называемыми собирателями материалов для биографии Гоголя, если бы я захотел похвастать перед моими читателями моим знакомством с ним, - я мог бы напечатать и мои воспоминания о нем. В этих воспоминаниях я, конечно, уже не позволил бы себе увлекаться фантазией и начал бы их, например, хоть так: “Один из старинных знакомых Гоголя...”, - начал Новый поэт ${ }^{22}$; далее он в деталях рассказал о встрече с Гоголем (об этих деталях - ниже), а завершил следующим пассажем: «Из этого отрывка, заимствованного из моих воспоминаний о Гоголе, биографы его могут, по крайней мере, вывести заключение, что Гоголь любил малагу, а из иных воспоминаний об нем не выжмешь даже и такого факта. Что если бы этот великий комик мог взглянуть теперь на своих биографов?..»²3. Намеренная двусмысленность сообщения очевидна, и этого, на наш взгляд, достаточно, чтобы задуматься - в какой степени «воспоминание» о встрече стилизовано и сочинено для примера, а в какой - включает реальные подробности, извлеченные Новым поэтом из памяти Панаева.

Коль скоро фельетонист лишь намекает, что вставной мемуар - стилизация для примера того, как мог бы и он, если бы захотел, «похвастать» знакомством с Гоголем и как «усердие собирателей материалов для биографии Гоголя, к сожалению, иногда совсем не бескорыстное, доходит до

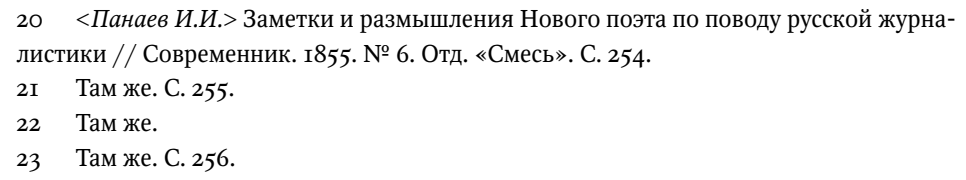


смешного» ${ }^{24}$, то и исключить, что Панаев подобрал подходящий пример из многого, что помнил, - мы тоже не можем. Не можем - исключить, но увеличить долю сомнения в этом, и существенно увеличить - можем.

Расширим, пока совсем немного, поле обозрения, и в предшествующем номере «Современника» за тот же год - в фельетоне из той же серии «заметок и размышлений» о русской журналистике - обнаружим еще одно «воспоминание» Панаева, тоже приведенное им для примера (в этом случае - романтизированной прозы), перед критикой лжеромантических литературных настроений вообще и в одном рассказе И.С. Тургенева в частности, что и прописано в анонсе ${ }^{25}$. Никаких сомнений в пародийности этого «воспоминания» нет ${ }^{26}$, хотя в строгом смысле можно признать, что фельетонист припомнил свои собственные романтические иллюзии (как в своих фельетонных пародиях на Н.В. Кукольника или на В.Г. Бенедиктова - свое увлечение ими). Словом, мемуарный фрагмент о Гоголе, может статься, реализует характерный фельетонный прием, в котором мемуарная форма одна из свойственных Новому поэту форм пародирования посредственных (в глазах редакции) литературных образцов - драматического, стихотворного и прозаического типа ${ }^{27}$.

Впрочем, в отличие от «воспоминания» о приятеле с байроническими приметами и наклонностями, описание Новым поэтом гоголевской встречи полно, как упоминалось, подробностей. Точное время (собрались литераторы «часам к осьми», «Гоголь явился в го часов», «в половине двенадцатого <...> взялся за шляпу»), внешность (черный сюртук, «волосы его падали длинными тесьмами спереди и сзади», «усики и бородка» и т. п.) и поведение («довольно равнодушно поздоровался» с хозяином, «окинул

24 Там же. С. 259.

$25<$ Панаев И.И.> Заметки и размышления Нового поэта по поводу русской журналистики // Современник. І855. № 5. Отд. «Смесь». С. І23.

26 Ср.: «..предлагаемый мною отрывок из моих воспоминаний приводится здесь не случайно и не без цели. Этот приятель мой был существо не совсем обыкновенное <..> худощав, бледен, вечно задумчив и вечно рассеян. Его блуждающий неопределенный взгляд, его кудри до плеч <...>. Он напоминал то Ленского, то принца Гамлета... <...>. В двадцать пять лет он писал стихи, пробовал переводить Шиллера, Гете, Байрона и Гейне <...>. Как бы то ни было, но он, как Ленский, унес с собой в могилу тайну своего таланта, если только имел его» (курсив наш. - Е.П.). См.: <Панаев И.И.> Заметки и размышления Нового поэта по поводу русской журналистики // Современник. І855. № 5. Отд. «Смесь». С. ІІ3.

27 О пародийности литературной маски Нового поэта, предтечи Козьмы Пруткова, см.: [16, с. I57-ı68]; в аспекте эволюции явления (от маски барона Брамбеуса) см.: [Іо, с. 83-88]. 
быстрым, но едва заметным взглядом всех присутствующих», среди молодежи «уселся на диване, посматривая на все и на всех как-то вяло, флегматически» и т. п.); передано (бегло, правда) содержание разговора («с любопытством и видимым участием расспрашивал их о их будущих трудах, отзываясь о некоторых напечатанных их произведениях с большою похвалою») и - подробно изложено произнесенное Гоголем по бытовому поводу (ужин, чай, выбор вина) ${ }^{28}$. На вид правдоподобно, хотя о знаменательной встрече, по сути, - ничего конкретного. Но ведь фельетонный мемуарист и настаивал на значении только одной, пусть маленькой, но «точной» биографической подробности - на том, что Гоголь любил малагу. А потому - обратим и мы внимание на эту, фельетонистом подчеркнутую, «фактическую» часть «вспомянутого». Гоголь отказался от предложенной еды («я никогда не ужинаю», «это вредно»), по поводу вина ответил вопросом - «какое у вас есть вино?», но из перечня («лафит, сотерн, мадера, портвейн, шампанское») ничего не выбрал («я этого ничего не пью») и попросил рюмку малаги. «Слова эти были решительным ударом для хозяина дома... О малаге ему и в голову не приходило. Кто же пьет малагу?» ${ }^{29}$. Заметим, что относительно нейтральный до этого тон описания поведения Гоголя снизился до карикатуры, а биографам предложено учесть явную странность его вкусовых предпочтений.

Автор-составитель новейшей ЛЖТ Гоголя, приведя полностью соответствующий фрагмент фельетона Нового поэта как «воспоминание» И.И. Панаева І855 г., объяснил биографическое значение «факта» с выбором вина: «Поведение Гоголя носило, по-видимому, “знаковый” характер. В стихотворении его покойного друга, поэта Н.М. Языкова "Малага” это вино как “напиток смирный и беспенный” противопоставляется “кипучим” винам, которые герой пил в разгульные годы юности, когда - "все было наобум” [5, с. І7о]. Мы тоже уверены, что в номинировании фельетонистом этого вкусового пристрастия Гоголя как «по крайней мере» одного надежного биографического факта - все дело в Языкове и в этом его стихотворении в том числе. Только подоплеку мы видим совсем в другом.

$28<$ Панаев И.И.> Заметки и размышления Нового поэта по поводу русской журналистики // Современник. І855. № 6. Отд. «Смесь». С. 255-256.

29 Там же.. 
Дело в том, что Новый поэт в I855 г. вспомнил о тех временах, когда Языков находился под прицелом критики Белинского, Панаева и Некрасова, которые еще в период «Отечественных записок» поэтический стиль Языкова признавали анахронизмом, не находя в нем ничего, кроме такой же лжеромантической гладкости, как у не менее «любимых» ими Кукольника и Бенедиктоваз ${ }^{30}$ А после известных стихотворных памфлетов Языкова на западников («К не нашим», «Константину Аксакову» и т. д.; рубеж I844/I845 гг.), сразу распространившихся в списках, Белинский в статье «Русская литература в I844 г.» (первый номер «Отечественных записок» за I845 г.) выбрал особо язвительный способ критики, написав, в частности, что Языков «рассказывал в удалых стихотворениях более всего о своих попойках <...> нередко рассуждал в них и о том, что пора уже ему охмелиться» и публика наконец узнала «(из его же стихов), что он давно уже не может ничего пить, кроме рейнвейна и малаги; но дела до сих пор не видно» [2, с. 459; курсив наш. - E.П.]. Новый поэт откликнулся на это напутствие в первом номере «Современника» за І847 г., где фельетон вышел с шестью стихотворными пародиями (написанными Некрасовым [І6, с. І67]), и одна из них, под названием «Прогресс», - на Языкова, на ту же тему бражничества. При этом ритмической основой пародии стало то самое стихотворение «Малага» (см. подробно: [16, с. 167]), а языковское поэтическое противопоставление в нем пристрастия к «кипучим» напиткам в юности и умеренного вкуса к «беспенной» малаге в зрелости - составило в пародии суть «прогресса» от «забубенных бурсацких смут и бурь» к возрасту, когда «в права вступает мера» и - «не бражничаем мы с утра и до утра, / И развивает нас портвеин и мадера...», с надеждой на «желанную пору», когда - «Свое славянское достоинство сознав, / Ковшами будем пить напиток свой, народной» ${ }^{\text {I. }}$

30 Ср., например, атрибутируемое Некрасову стихотворение «К друзьям», в котором пародируется «Прощальная песня» Языкова и в целом его излюбленная тема дружеских студенческих пирушек, а в юмористическом предисловии к фельетонной публикации сказано, что «романтическая поэзия не совсем умерла <...>, снова запела свои удалые и хмельные песни» (см.: Литературные и журнальные заметки // Отечественные записки. І843. № I. Отд. VIII. C. 54); см. об этой и о других некрасовских пародиях на стихи Языкова: [І6, с. I6о, I64]. 3I Новый поэт // Современник. I847. T. І. № I. Отд. IV. С. 68. Ср. в предисловии Нового поэта к своим стихам: «Может быть, нет человека, который помнил бы и десятую долю тех русских поэтов, которых я читал, которыми восхищался... <... >. Но особенно любил я, разумеется, Бенедиктова, Языкова, Хомякова, Кукольника. Бурная, клокочущая, гремящая и сверкающая поэзия Бенедиктова, удалой, широкий разгул Языкова - как было устоять против них?.. Мне казалось, что я не могу ни так чувствовать, как Бенедиктов, ни так пить и 
Так что ответ на вопрос Нового поэта из фельетона I855 г. - «Кто же любит малагу?» - был хорошо известен Панаеву, действительно, можно сказать, вспомнившему реальность конца I840-х гг., и имел при этом несомненное отношение к Гоголю - и не только как к другу Языкова. Вспомним, что в январе I847 г. вышла гоголевская книга «Выбранные места из переписки с друзьями», вызвав резко отрицательную критику Белинского (опубликованную во втором номере «Современника» за тот же год) и его знаменитое «Письмо к Гоголю» (от І5 июля н. ст. из Зальцбрунна). В конце года солидарным образом проявил себя и Новый поэт. В декабрьском номере журнала за тот же год среди «Современных заметок» напечатано «письмо Нового поэта к издателям “Современника”, и речь литературной маски с простодушным самомнением графомана пересыпана аллюзиями к образу автора «Выбранных мест... (в трактовке Белинского) и парафразами из книги и «Предисловия» ко второму изданию поэмы ${ }^{32}$. Но если в «письме Нового поэта» аллюзии к гоголевской книге соседствуют с другими объектами критик Белинского («патриотизм» Н. Полевого, к примеруз3), то после «письма» следует еще одна пародия на Гоголя - «Выбранные места из приятельских писем», предваренная рассуждением о том, как удобно иметь приятелей в Петербурге, если ты живешь вдалеке от столицы, «в доказательство» чего сообщено «несколько извлечений из хранящейся у меня коллекции приятельских писем, от разных Пиладов к многоразличным Орестам. Коллекция эта замечательна во многих отношениях, но теперь я выбираю из нее только то, что касается до взаимных приятельских услуг» 34 . Почему, возникает теперь вопрос, летом I855 г. редакция «Современника» в лице Панаева-фельетониста возобновила гоголевскую тему с аллюзионным вектором к стихам Языкова? На наш взгляд, причина в литера-

\footnotetext{
предаваться разгулу, как Языков, и подавленный их величием, я падал перед ними в прах». См.: Новый поэт... С. 65-66.

32 Ср., например, в стихотворной форме: «В груди моей и буря и смятенье, / Святым восторгом вечно движим я, / Внимает мне Россия с умиленьем.../ Чего же Русь ты хочешь от меня?» (См.: Современные заметки // Современник. 1847. № 12. Отд. «Смесь». С. 187) (указано в: [16, с. 158]).

33 Ср. частую у Белинского цитату из «Клятвы при гробе Господнем» (І832): «...скажу, отбросив всякое самолюбие, но с правым сознанием собственного достоинства, как сказал некогда о себе один русский писатель: Я знаю Русь - и Русь меня знает!». См.: Современные заметки... С. І88; курсив в оригинале.

34 Современные заметки... С. г94. Курсив в оригинале.
} 
турной ситуации середины I850-х гг., в конкуренции трех ведущих толстых журналов («Современник», «Отечественные записки» и «Москвитянин»), а самоопределение по отношению к Гоголю (сатирик и основатель «натурального» направления или автор «Переписки с друзьями») было едва ли не ключевым вопросом еще с рубежа I840/І850-х гг. (наряду с выбором позиции по отношению к наследию Пушкина и Белинского 35 ). Характерно, в частности, что за мемуарной частью панаевского фельетона I855 г. следует критика Новым поэтом спекуляции на гоголевском имени «Библиотеки для чтения» (что «принялась теперь за Гоголя» в котором Сенковский прежде «едва удостаивал замечать проблески истинного таланта и находил даже, что он был не совсем в своем уме», а теперь журнал находит «даже высокий ум и желает воздать справедливость автору “Мертвых душ”»36). Однако критика в этом случае мнимая, в ее подкладке - солидарность, и она подчеркнута согласием с «остроумным примечанием к этим письмам» в «Библиотеке для чтения», процитированным в фельетоне: «Хотя бо́льшая часть новых писем принадлежит к известному эпистолярному роду Гоголя, роду, в котором ум и мысль как будто находятся в отпуску, однако некоторые письма, особенно третье из числа ныне здесь напечатанных, отличаются истинно писательскими достоинством и <... высоким умом» и далее ${ }^{37}$. А «остроумие» «Библиотека...» проявила в том, что после грубого выпада против автора «Выбранных мест...» напечатала три его письма разных лет к А.С. Данилевскому, особо подчеркнув (см. выше) ценность третьего (от г3 апреля н.ст. І844 г. из Франкфурта) - с теми же воззрениями на жизнь, что и в книге. Это последнее письмо и перепечатано в фельетоне. Таким причудливым, но характерным для журнальной литературной полемики тех лет, образом «Современник» критиковал позицию «Москвитянина», благожелательно, как известно, отнесшегося к «Выбранным местам...». Учитывая, что Гоголь много места в своей книге уделил стихам Языкова, причем - в сопоставлении с пушкинской лирикой, а Белинский пред тем ополчился на Языкова за памфлеты, перед нами хоть и косвенное, но воспоминание (хотя и не о Гоголе), а в то же время - остроумная форма полемики.

35 О последнем см.: [4, с. 22-27].

$36<$ Панаев И.И.> Заметки и размышления Нового поэта по поводу русской журналистики // Современник. г855. № 6. Отд. «Смесь». С. 256; курсив в оригинале.

37 Там же. С. 257, курсив фельетониста. 
Итак, совершенно очевидно, что для Панаева-фельетониста поздний Гоголь был не столько современником, память о котором надо сохранить для потомков, сколько «фигурантом» в важной полемической теме, а текст вставленного в фельетон Нового поэта «воспоминания» не может быть признан источником биографических данных. А потому, как минимум, мы вообще сильно сомневаемся даже в том, что Гоголь действительно любил малагу.

О малаге - еще пару слов. В свое время (1963) панаевское сообщение о гоголевском предпочтении легло в основу предположения американского исследователя Ю. Маргулиеса, что на том же вечере у А. Комарова присутствовал и Достоевский, коль скоро в «Селе Степанчикове...» (1859) есть эпизод, где Фома Опискин требует подать ему малаги [I5]. Развернулась дискуссия о вероятности участия Достоевского и объекте пародии его персонажа (см. библиографический обзор: $[5, \text { с. I73-I74 }]^{88}$ ). Мнение по этому поводу обоих новейших биографов Гоголя в целом солидарное, отрицающее участие Достоевского по причине осложнения к тому времени его отношений с кружком Белинского [14, с. I53; 5, с. I72-I73], а в ЛЖТ Виноградов добавил к этому еще один аргумент, справедливо указав на то, что про малагу Достоевский мог узнать и из «рассказа Панаева в публикации I855 г.» [5, с. I7I]. Согласны оба биографа и с тем, что упоминание малаги в «Селе...» метило в Гоголя. В этой связи автор ЛЖТ приводит пространное «оправдание» Достоевского, видя его во влиянии (еще не изжитом писателем) западников, исказивших образ автора «Переписки с друзьями» [5, с. I72]. Позвольте, мог бы спросить по этому поводу Новый поэт, зачем же тогда включать меня, приложившего руку к очернению, в биографию Гоголя? Но вернемся к фактам. Приведенный биографами аргумент против участия Достоевского уже был высказан Н.В. Первушиным в г97 г г., наряду с другими, тоже убедительными, доводами [І9]. Им же было указано, что Тынянов, чья мысль о пародийности «Села...» повлияла на мнение Маргулиеса и автора ЛЖТ, внятно оговорил, что пародирование вообще и Достоевским стиля «Выбранных мест...» в частности вовсе не предполагает обязательного отрицания и осуждения произведения в целом [I9, с. I70-I72]. Первушин справедливо сослался также на собирательный характер образа Фомы [І9,

38 Странно только, что обзор открывается известной статьей Ю. Тынянова, этого вопроса не касавшегося. 
c. I72]. Мы в свое время исследовали этот вопрос, и анализ показал, что в большей степени, чем Гоголь, у Достоевского пародируются его эпигоны и критики книги [I7, с. I4], а внимание к панаевскому фельетонному «воспоминанию» позволяет назвать один из конкретных адресов пародии. Напомним для этого, как в «Селе... на требование Фомой малаги отреагировал Бахчеев «в самой последней степени негодования»: «Малаги захотел! <...> И вина-то такого спросил, что никто не пьет! Ну, кто теперь пьет малагу, кроме такого же, как он, подлеца?» [8, с. I45]. А сомнений, что Достоевский знал происхождение и цель этого вопроса в панаевском фельетоне, у нас нет. Он сотрудничал с «Современником» в середине I840-х гг., когда всячески склонялось имя Языкова, в числе прочего - по части любви к малаге, а кроме того у Достоевского в «Петербургских сновидениях в стихах и прозе» (Время. I86I. № I) объектом пародирующей и прямой критики жанра стал именно Новый поэт, в числе прочего - в форме псевдовоспоминания и со ссылкой на последование Булгарину, не отличавшемуся щепетильностью мемуаристу и фельетонисту.

Вернемся к самому Панаеву, который по прошествии еще пяти лет включил тот же эпизод в свое «Воспоминание о Белинском», опубликованное, уже с собственной подписью, в «Современнике» в г860 г. 39 Историки литературы, используя именно эту редакцию, как мы уже говорили, правы в том, что ее хотя бы можно рассматривать как мемуарный (а не фельетонный) текст, применяя соответствующие способы дезавуации. Конечно, и без истории панаевских текстов их фактологическая сторона требует тщательной проверки в силу того уже, что не столько память его была плохой, сколько установки совершенно соответствовали беллетристическим и фельетонно-полемическим целям (см. об этом подробно: [18]) $4^{40}$. Посмотрим тем не менее, какова авторская стратегия Панаева - вспоминателя о позднем Гоголе - в г86о г.

Примечательно: он поместил в мемуары о Белинском тот же эпизод, но - не тот же текст ${ }^{4}$. Стиль стал сдержаннее, содержание насытилось

39 Панаев И.И. Воспоминание о Белинском // Современник. г86о. Т. 79. № т. С. 364-366. 40 Ср. с такой же ролью прагматического фактора в беллетристическом, фельетонном и мемуарном образах Н. Кукольника у Панаева: [гт].

4I Любопытно, что в новой редакции он сместил все ссылки на точное время дня ровно на полчаса ближе к ночи (зачем и почему - вопрос, наводящий на размышления о природной веселости автора). 
«фактами»: прямо назван хозяин дома (А.А. Комаров), литераторы (Гончаров, Григорович, Некрасов, Дружинин), прежде - «молодые», а теперь «известные новые»; по другому мемуарист, не будучи ни «молодым», ни «новым» (родился в І8г2 г. и начал печататься в I828 г.), вписал свое участие («был в числе приглашенных, хотя был давно уже знаком с Гоголем» ${ }^{42}$ ).

Важно: отредактирован образ позднего Гоголя. В фельетонной редакции образа привыкшего к славе маститого писателя подчеркнуто, как мы видели, снисходительное, но в целом доброжелательное отношение к молодежи и в человеческом облике акцентированы самоуглубленность и до комизма доходящие бытовые странности. Иначе в рамках повествования о Белинском, где Гоголь уже - не очень симпатичный человек: «Белинский был в энтузиазме от Гоголя, как писателя - это всем известно, но как с человеком он никогда не мог сойтись с ним близко. Гоголь <...> начинал приобретать постепенно неприступность авторитета, все более и более сближаясь с другими литературными и светскими авторитетами. Открытый и искренний по натуре Белинский не терпел никакой напыщенности и натянутости и признавался, что ему всегда было немного тяжеловато в присутствии Гоголя» ${ }^{4}$. Этот нарастающий снобизм в поведении влиятельного литератора «эпохи Белинского» Панаев и подчеркнул «вспомнившимся» эпизодом, не имеющим отношения к жизни критика: «Упомянув о неприступности Гоголя и странном обращении с его старыми приятелями, я кстати <...> расскажу об одной встрече (это уже было года два или три после смерти Белинского)»44. Остальные редакторские изменения - совершенно соответствуют поставленной задаче. Жестче очерчена поза Гоголя в отношении к новому литературному поколению - отстраненная и не без высокомерия: «...взглянул бегло на всех, подал руку знакомым, отправился в другую комнату и разлегся на диване. Он говорил мало, вяло, нехотя, распространяя вокруг себя какую-то неловкость, что-то принужденное» 45 ; когда его познакомили с молодежью, «Гоголь несколько оживился, говорил с каждым из них об их произведениях, хотя было очень заметно, что не читал их. Потом он заговорил о себе и всем нам дал почувствовать, что его знаменитые “Письма” пи- 
саны им были в болезненном состоянии, что их не следовало издавать, что он очень сожалеет, что они изданы. Он как будто оправдывался перед нами» ${ }^{6}$. В последнем случае Панаев, казалось бы, не сообщил ничего нового (современникам была известна по многочисленным спискам «прощальная повесть», или «авторская исповедь», Гоголя) и для нас неправдоподобного [I4, c. I52], но дал, однако, между делом понять, что автор «Переписки с друзьями...» и сам был солидарен с нелицеприятной оценкой книги передовой критикой.

Все это лишний раз подчеркнуто в новой концовке гоголевского эпизода, где убран, разумеется, смешливый риторический вопрос Нового поэта о странности выбора малаги, а в конце эпизода взамен насмешки над биографами прибавлено: «Не знаю, как другим, - мне стало как-то легче дышать после его отъезда...»47. И то сказать, не мог соратник Белинского тоже не почувствовать «напыщенность» и «натянутость» Гоголя-человека, во всяком случае в мемуарной повести о великом критике, написанной в г86о г., когда образ последнего вновь обрел значение главы литературы, в числе прочего - усилиями «Современника» [3, с. I70-I74]; с другой стороны, и мнение проницательного Белинского не было, согласно этой концовке, субъективным, то же чувствовали в Гоголе и другие.

Кстати, о других. Ровно то же впечатление от позднего Гоголя сохранилось в памяти Некрасова, и всплыло оно тоже в связи с Белинским - в разговоре с А.С. Сувориным в начале I875 г. Последний в тот же день (I6 января) записал в дневник, а позднее - в г878 г. обнародовал в своей газете следующий рассказ поэта: «А как на нас смотрели тогда - я не говорю о властных особах, а напр., такие знаменитости, как Гоголь. Раз он изъявил желание нас видеть. Я, Белинский, Панаев и Гончаров надели черные фраки и поехали представляться, как к начальству. Гоголь и принял нас, как начальник принимает подчиненных: у каждого что-нибудь спросил и каждому что-нибудь сказал» ${ }^{4}$. И что примечательно! Суворин тоже отредактировал для печати свою дневниковую запись (просто бедствие какое-то). В дневнике-то к писательской позе Гоголя относится только выражение «немножко ломался и выглядел избалованным» [6, с. 643]; тоже нелице-

46 Там же. С. 365-366.

47 Там же. С. 366.

48 Новое время. І878. г янв. № 662. С. 4. 
приятная формулировка, но к психологии начальника отношения не имеет. И не то чтобы через три года Суворин вспомнил больше, а просто так же, как Панаев, придал материалу более привлекательную для читателя форму. Ведь источник «мемуарного» образа «начальника» в газетной публикации легко опознается по междометию, которое Суворин-редактор приписал Гоголю в качестве реакции на странное, к слову сказать, заявление Некрасова: «Я читал ему стихи “К Родине”. Выслушал и спросил: “Что ж вы дальше будете писать?” - “Что Бог на душу положит”. - “Гм”, - и больше ничего»49 (а что тут скажешь?..). Это именно междометие «после каждого слова» произносил гоголевский персонаж - Его высокопревосходительство из пьесы «Утро делового человека»50. Суворина - известного театрала - можно понять, нам тоже по мере поиска достоверного зерна «литературных воспоминаний» о встрече припоминаются разные реплики гоголевских персонажей, к примеру - возглас Бурдюкова («Тяжба») о наследстве: «...я спрашиваю, на что мне штаметовые юбки?» Впрочем, разночтений дневника и публикации в упоминании участников разговора (Белинский, Панаев и Гончаров) нет.

Теперь - кстати, об участниках. Исходя из разнообразия мотивов и установок Панаева и Некрасова, стоит задуматься, почему «молодые литераторы» - Гончаров, Григорович и Дружинин - ни словом, ни полусловом не отозвались о встрече, знаменательной для них, казалось бы, пусть и в меньшей степени, чем для Пушкина чтение стихов в присутствии Державина. Немаловажен и еще один вопрос: почему Панаев или Некрасов не вспомнили об Анненкове, только-только вернувшемся из-за границы постоянном корреспонденте «Современника» - авторе «Парижских писем»? Между тем с Анненковым-то Гоголь точно виделся той осенью, после чего (24 сентября) написал А.С. Данилевскому об этом [7, т. XIV, с. 87]. Или он имел в виду другую встречу?

Сам Анненков в «памятных заметках» («Две зимы в провинции и деревне»), составленных не ранее конца I877 г. и не предназначавшихся для

49 Там же. Ср. в дневнике: «Я читал ему стихи “К Родине”. Выслушал и спросил: “Что ж вы дальше будете писать?” - “Что Бог на душу положит” [6, с. 643].

50 Так Александр Иванович описал речь начальника: «Его высокопревосходительство после каждого слова говорил “гм!”, а на настойчивые просьбы Пролетова повторить благожелательный отзыв о нем лично отвечал одно и то же: «Гм!», сказал его высокопревосходительство, «это человек...» [7, т. V, с. І05]. 
печати ${ }^{51}$, припомнил отношение Гоголя в последний, московский, период к цензуре как к небесполезному и не вечному ограничению и добавил, что «эту же мысль» Гоголь «развивал» «на вечере у Александра Комарова» в присутствии мемуариста и - Некрасова, «опешившего» и возразившего, что «ведь за все это время надо еще есть» ${ }^{22}$. Точная дата Анненкову тоже не вспомнилась, и он указал на І849 г.

Уверенности новейших биографов в том, что в анненковской мемуарной заметке речь идет о той же встрече, что и у Панаева [I4, с. I5I; 5, с. I69], мы не разделяем. Вызывает серьезные сомнения и убеждение обоих биографов в том, что Анненков в г858 г. (в письме И.С. Тургеневу от 3 февраля) вспомнил о том же эпизоде, написав: «Помню я, что в I849 г. Гоголь находил необычайную пользу для литературы в тогдашней системе цензурного ограничения» [I4, с. I5I; 5, с. І69]. Как справедливо указывает Ю.В. Манн, комментируя изложение Анненковым позиции Гоголя по цензурному вопросу, мысль о том, что «автор, ввиду возможного вмешательства цензуры, должен уметь так говорить “свою правду”, чтобы ее выслушали все», - «Гоголь особенно настойчиво проводил в "Выбранных местах...” (в частности, в статье “Карамзин”)» [І4, с. I53]. Так почему же мы полагаем, что устно Гоголь высказался об этом лишь однажды? Того, что в обоих случаях упомянут Некрасов, о чьих других встречах с Гоголем ничего не известно, на наш взгляд, недостаточно. Нельзя исключить, что Анненков «вспомнил» о реакции Некрасова под влиянием уже опубликованного Сувориным устного воспоминания поэта, невольно совместив два разных впечатления. К слову сказать, все обсуждаемые нами мемуаристы были знакомы с воспоминаниями И.И. Панаева, и фактор подспудного влияния на последующих вспоминателей живо рассказанного им эпизода в доме А.А. Комарова - тоже исключить нельзя (такие прецеденты в мемуаристике известны и неоднократно отмечены комментаторами).

Итак, полный комплекс разных данных о гоголевской встрече с «литературной молодежью» конца І840-х гг. позволяет считать, что мемуарные сообщения возникли не на пустом месте. Но никакой твердой уверенности в том, что Панаев, Некрасов и Анненков вспомнили об одной и той же встре-

5I B г892 г. Л.Н. Майков выделил из них и опубликовал лишь фрагмент о Гоголе, уже способный пройти цензуру. См.: Последняя встреча с Гоголем... С. VII.

52 Последняя встреча с Гоголем... С. 5I5. 
че, из имеющихся сведений извлечь невозможно. Вряд ли возможно также доискаться точной фактической основы этого, искаженного памятью мемуаристов, эпизода гоголевской биографии, если он и был. А вот феноменологическая сторона этого сегмента мемуаристики о Гоголе весьма показательна, и мифопорождающие тенденции в ней лишний раз свидетельствуют о насущности систематического и системного изучения всех мемуаров о Гоголе в источниковедческом аспекте.

Напоследок позволим себе посетовать на присоединение к тенденции мифопорождения автора ЛЖТ, увеличившего апокрифический компонент - в номинации события. Мы имеем в виду не только отсутствие ссылок на вероятностный характер и недопустимое доверие к сообщенному А.Я. Панаевой, но и заимствование у нее утверждения, что Гоголь пожелал

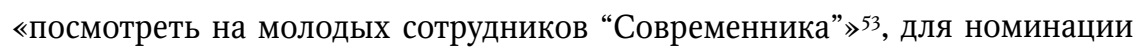
события в ЛЖТ [5, с. І69]. Никто из вспоминателей, могущих быть участниками, так гоголевскую инициативу не описывал, зачем же превращать желание мемуаристки ${ }^{54}$ в факт биографии Гоголя, приписывая ему - такое желание?..

\section{Список литературы}

I Архипова А.В. Примечания // Достоевский Ф.М. Полн. собр. соч.: в 30 т. Л.: Наука, 1972. Т. 3. С. 496-516. Белинский В.Г. Полн. собр. соч.: в гз т. [М.; Л.]: Изд-во АН СССР, І955. Т. VIII. $728 \mathrm{c}$.

3 Вдовин А.В. Концепт «глава литературы» в русской критике 1830-60-х годов. (Dissertationes philologiae slavicae universitatis tartuensis.) Tartu, 20II. $238 \mathrm{c}$.

4 Вдовин А.В., Зубков К.Ю. «Спор Петербурга с Москвою». Литературная полемика первой половины I850-х годов // «Современник» против «Москвитянина». Литературная полемика первой половины 1850-х годов. СПб.: Нестор-История, 2015. C. 7-33.

5 Виноградов И.А. Летопись жизни и творчества Н.В. Гоголя: в 7 т. М.: ИМЛИ РАН, 20I8. T. 6.656 c.

53 Воспоминания А.Я. Головачевой (Панаевой). Гл. VIII. С. 54.

54 У Панаевой фигуры Белинского, Панаева и Некрасова рисуются именно в связи с созданием журнала, а кроме того - не исключено, что ей хотелось показать, как Гоголь автор «Выбранных мест...», ожесточенно раскритикованных «Современником», - пытался наладить с редакцией хорошие отношения. 
Гоголь в воспоминаниях, дневниках, переписке современников. Полный систематический свод документальных свидетельств: в 3 т. / изд. подгот. И.А. Виноградов. М.: ИМЛИ РАН, 2ОІ3. Т. 3. ІІ68 с.

Гоголь Н.В. Полн. собр. соч.: в І4 т. [М.; Л.]: Изд-во АН СССР, І949, I952. T. V, XIV. $5 \mathrm{I} 2 \mathrm{c.}+487$ c.

8 Достоевский Ф.М. Полн. собр. соч.: в 30 т. Л.: Наука, І972. Т. 3. 543 с.

9 Елизаветина Г.Г. Комментарии к тексту «Две зимы в провинции и деревне с генваря I849 по август І85І года» // П.В. Анненков. Литературные воспоминания. М.: Худож. лит., І983. С. 647-653. Зыкова Г.В. Поэтика русского журнала І830-І870-х гг. М.: МАКС Пресс, 2005. $200 \mathrm{c}$.

Зыкова Г.В., Карева А.Ю. Нестор Кукольник в повести, фельетоне и воспоминаниях Панаева: три разных портрета одного лица // Вестник Московского университета. Сер. 9. Филология. 2009. № 2. С. I40-I49.

Кошелев А.В. Пушкин в воспоминаниях: проблемы изучения литературных мемуаров. Великий Новгород: Издат.-полиграфич. центр Новгородского гос. ун-та им. Ярослава Мудрого, 20II. I83 с.

I3 Лотман Ю.М. Литературная биография в историко-культурном контексте (к типологическому соотношению текста и личности автора) // Литература и публицистика. Проблемы взаимодействия. Труды по русской и славянской филологии. Уч. зап. Тартус. гос. ун-та. Вып. 683. Тарту: Тартуский гос. ун-т, І986. С. Іо6-І2I.

I4 Манн Ю.В. Гоголь. Завершение пути: І845-I852. М: Аспект Пресс, 2009. 304 с.

I5 Маргулиес Ю.Э. Встреча Достоевского и Гоголя (начало осени І848 года) // Воздушные пути (Нью Йорк). г963. № 3. С. 272-294.

I6 Мельгунов Б.В. Некрасов, Панаев - Новый поэт (К истории создания литературной маски) // Русская литература. 1986. № 3. С. 153-169.

I7 Падерина Е.Г. Гоголь и Достоевский. Проблема образа автора: автореф. дис. ... канд. филол. наук. Л., І990. 27 с.

I8 Падерина Е.Г. О тяжбе по поводу «Тяжбы» и проблемах датирования хорошо запомнившегося современникам эпизода биографии Гоголя // Studia Litterarum. 20I7. T. 2, № 2. С. 290-3I5.

I9 Первушин Н.В. Встречался ли Достоевский с Гоголем // Новый журнал (Нью Йорк). І97І. Кн. І05. С. I64-I72. 


\section{References}

Arhipova A.V. Primechaniia [Notes]. In: Dostoevskii F.M. Polnoe sobranie sochinenii: v 30 t. [Complete works: in 30 vols.]. Leningrad, Nauka Publ., I972, vol. 3, pp. 496-5I6. (In Russ.)

Belinskii V.G. Polnoe sobranie sochinenii: $v$ I3 t. [Complete works: in I3 vols.]. [Moscow, Leningrad], AN SSSR Publ., I955. Vol. VIII. 728 p. (In Russ.)

3 Vdovin A.V. Kontsept "glava literatury" $v$ russkoi kritike I830-6o-kh godov [The concept of the "head of literature" in Russian criticism of the I830-6os]. (Dissertationes philologiae slavicae universitatis tartuensis). Tartu, Tartu Ulikooli Kirjastus Publ., 20II. 238 p. (In Russ.)

$4 \quad$ Vdovin A.V., Zubkov K.Iu. "Spor Peterburga s Moskvoiu”. Literaturnaia polemika pervoi poloviny I850-kh godov ["The dispute of St. Petersburg with Moscow." Literary polemics of the first half of the I850s]. In: "Sovremennik" protiv "Moskvitianina". Literaturnaia polemika pervoi poloviny I850-kh godov [“Sovremennik” vs “Moskvityanin." Literary polemics of the first half of the I85os]. St. Petersburg, Nestor-Istoriia Publ., 2015, pp. 7-33. (In Russ.)

5 Vinogradov I.A. Letopis' zhizni i tvorchestva N.V. Gogolia: $v 7 t$. [The chronicle of the life and work of Nikolay Gogol: in 7 vols.]. Moscow, IWL RAS Publ., 20I8. Vol. 6. 656 p. (In Russ.) Gogol'v vospominaniiakh, dnevnikakh, perepiske sovremennikov. Polnyi sistematicheskii svod dokumental'nykh svidetel'stv: $v 3 t$. [Gogol in memoirs, diaries, and correspondence of his contemporaries. A complete and systematic set of documentary evidence: in 3 vols.], ed. I.A. Vinogradov. Moscow, IWL RAS Publ., 20I3. Vol. 3. II68 p. (In Russ.) Gogol N.V. Polnoe sobranie sochinenii: $v$ I4 $t$. [Complete works: in I4 vols.] Moscow, Leningrad, Izdatel'stvo AN SSSR Publ., I949. Vol. V. 5I2 p. I952. Vol. XIV. 487 p. (In Russ.)

8 Dostoevskii F.M. Polnoe sobranie sochinenii: $v$ zo t. [Complete works: in 30 vols.]. Leningrad, Nauka Publ., I972. Vol. 3. 543 p. (In Russ.) Elizavetina G.G. Kommentarii $k$ tekstu "Dve zimy v provintsii i derevne s genvaria I849 po avgust I85I goda" [Comments on the text "Two winters in the province and the village from January I849 to August I85I”]. In: P.V. Annenkov. Literaturnye vospominaniia [Annenkov P.V. Literary memories]. Moscow, Khudozhestvennaia literatura Publ., I983, pp. 647-653. (In Russ.) Zykova G.V. Poetika russkogo zhurnala I830-I870-kh gg. [Poetics of the Russian journal of the I830s-I870s]. Moscow, MAKS Press Publ., 2005. 200 p. (In Russ.) Zykova G.V., Kareva A.Ju. Nestor Kukol'nik v povesti, fel'etone i vospominaniiakh Panaeva: tri raznykh portreta odnogo litsa [Nestor Kukol'nik in the story, feuilleton, and memoirs of Panayev: three different portraits of the same person]. Vestnik Moskovskogo universiteta, ser. 9, Filologiia, 2009, no 2, pp. I4O-I49. (In Russ.) 
Koshelev A.V. Pushkin v vospominaniiakh: problemy izucheniia literaturnykh memuarov [Pushkin in memoirs: problems of studying literary memoirs]. Velikii Novgorod, Izdatel'sko-poligraficheskii tsentr Novgorodskogo gos. universiteta im. Iaroslava Mudrogo Publ., 20II. I83 p. (In Russ.)

I3 Lotman Ju.M. Literaturnaia biografiia v istoriko-kul'turnom kontekste (k tipologicheskomu sootnosheniiu teksta i lichnosti avtora) [Literary biography in historical and cultural context (on the typological correlation of the text and the author's personality)]. In: Literatura i publitsistika. Problemy vzaimodeistviia. Trudy po russkoi i slavianskoi filologii. Uch. zap. Tartus. goc. un-ta [Literature and journalism. Interaction problem. Works on Russian and Slavic Philology. Scientific notes of Tartu State University]. Tartu, Tartuskii gosudarstvennyi universitet Publ., I986, vol. 683, pp. I06-I2I. (In Russ.)

I4 Mann Ju.V. Gogol'. Zavershenie puti: I845-I852 [Gogol. The end of the road: I845-I852]. Moscow, Aspekt Press Publ., 2009. 304 p. (In Russ.)

I5 Margulies Iu.E. Vstrecha Dostoevskogo i Gogolia (nachalo oseni I848 goda) [A meeting of Dostoevsky and Gogol (early autumn I848)]. Vozdushnye puti (New York), I963, no 3, pp. 272-294. (In Russ.)

I6 Mel'gunov B.V. Nekrasov, Panaev - Novyi poet (K istorii sozdaniia literaturnoi maski) [Nekrasov, Panaev - the New poet (On the history of literary masks)]. Russkaia literatura, I986, no 3, pp. I53-I69. (In Russ.)

I7 Paderina E.G. Gogol' $i$ Dostoevskii. Problema obraza avtora: avtoref. dis. ... kandidata filologicheskikh nauk [Gogol and Dostoevsky. The problem of the author: PhD thesis, summary]. Leningrad, I990. 27 p. (In Russ.)

I8 Paderina E.G. O tiazhbe po povodu “Tiazhby" i problemakh datirovaniia khorosho zapomnivshegosia sovremennikam epizoda biografii Gogolia [On litigation concerning "Litigation": The problems of dating one episode of Gogol's biography]. Studia Litterarum, 20I7, vol. 2, no 2, pp. 290-3I5. (In Russ.)

I9 Pervushin N.V. Vstrechalsia li Dostoevskii s Gogolem [Did Dostoevsky meet Gogol?]. Novyi zhurnal (New York), I97I, no I05, pp. I64-I72. (In Russ.) 